\title{
Insufflation pressure required for thoracoscopic surgery and its influence on respiratory and cardiovascular parameters
}

\author{
VPinto $^{*}$, KB Galketiya ${ }^{2}$ \\ Senior Lecturer and Head ${ }^{l}$, Department of Anaesthesiology, Senior Lecturer ${ }^{2}$, Department of Surgery, \\ Faculty of Medicine, University of Peradeniya, Sri Lanka.
}

*Corresponding author: vasantipinto@yahoo.com

\begin{abstract}
Thoracoscopy is usually performed with one lung ventilation using a double lumen endotracheal tube. These surgeries can also be performed with a single lumen tube and double lung ventilation and the use of a capnothorax to cause a partial lung collapse. Lung collapse and capnothorax can cause adverse respiratory and cardio-vascular effects. Therefore the insufflation pressure needs to be safe and minimum.

Our study was to record respiratory, haemodynamic parameters and the insufflation pressure of the capnothorax created during thoracoscopy procedures.

With an insufflation pressure of $6-8 \mathrm{mmHg}$ an adequate lung collapse can be obtained for thoracoscopy. This pressure did not have any adverse respiratory or cardiovascular effects.
\end{abstract}

Keywords: thoracoscopy; capnothorax; insufflation pressure

\section{Introduction \\ Diagnostic and therapeutic procedures performed by thoracotomy or median sternotomy cause significant morbidity. ${ }^{1-6}$ Over the past two decades there is an emerging interest on performing the surgeries with thoracoscopy thereby significantly reducing the morbidity of the open access incision. ${ }^{7-11}$}

During thoracoscopic surgery it is necessary to create a space in the thoracic cavity in order to identify the anatomy of the structures and for instrumentation for dissection of tissues.

Providing access in the thoracic cavity for thoracoscopic surgery is challenging. Thoracoscopy is usually performed under general anesthesia with one lung ventilation using a double-lumen endotracheal tube or endobronchial blocker to collapse one lung to obtain the space. It is necessary to insufflate a certain volume of $\mathrm{CO}_{2}$ initially to collapse the lung which does not need to be continued. In our unit some surgeries are performed with a conventional single lumen endotracheal tube with double lung ventilation. In this instance capnothorax is used to cause the initial partial lung collapse and the capnothorax needs to be maintained throughout the surgery with continuous insufflation.

Causing a lung collapse and maintenance of a capnothorax are known to cause adverse respiratory and cardiovascular effects. The physiological homeostatic responses try to compensate to minimize possible resultant hypoxia and the reduction of pre load by maintaining the cardiac output.

Hence the $\mathrm{CO}_{2}$ insufflation pressures in both lung ventilator situations need to be safe and minimum.

At our unit a wide range of thoracoscopic procedures are performed with varying degrees of complexity. We reviewed all the cases to evaluate a $\mathrm{CO}_{2}$ insufflation pressure that is adequate to provide a satisfactory lung collapse and to report any complications.

\section{Material and Methods}

The thoracoscopic surgeries were performed using both single and double lung ventilation. At the beginning of the series procedures involving less dissection such as sympathectomy, splanchnicectomy, lymph node biopsy and lung biopsy were done with double lung ventilation. Complex procedures like oesophagectomy and thymectomy were done with single lung ventilation. However later in the series all procedures were done with double lung ventilation. 
After anaesthesia patients were placed supine for anterior and superior mediastinal procedures and prone for posterior mediastinal procedures. Initial insufflation pressure of $4 \mathrm{mmHg}$ was selected. The camera was inserted and the lung was observed for collapse. Then the working ports were introduced under vision. Adequacy of lung collapse was observed when there was clear vision of the lesion and the related anatomy to be dissected. The adequacy of the space provided for instrumentation was noted. The positioning used helped to retract the lung away from the field of dissection with the aid of gravity.

During the procedure respiratory and haemodynamic parameters were closely monitored and recorded. In double lung ventilation if the lung collapse was not found to be adequate the insufflation pressure was increased. The final insufflation pressure required was noted.

\section{Results}

A total number of 65 procedures were performed.

Table 1 Procedural details

\begin{tabular}{|c|c|c|c|c|c|c|c|c|}
\hline \multirow[t]{2}{*}{$\begin{array}{l}\text { Proced } \\
\text { ure }\end{array}$} & \multirow[t]{2}{*}{$\begin{array}{l}\mathrm{Nu} \\
\mathrm{mb} \\
\mathrm{er}\end{array}$} & \multicolumn{2}{|c|}{$\begin{array}{l}\text { Type of } \\
\text { ventilation }\end{array}$} & \multicolumn{2}{|c|}{$\begin{array}{l}\text { Average } \\
\text { insufflation } \\
\text { pressure }\end{array}$} & \multirow[t]{2}{*}{$\begin{array}{l}\text { Mean } \\
\text { blood } \\
\text { loss }\end{array}$} & \multirow[t]{2}{*}{$\begin{array}{l}\text { Avera } \\
\text { ge } \\
\text { Time }\end{array}$} & \multirow[t]{2}{*}{$\begin{array}{l}\text { Con } \\
\text { versi } \\
\text { on }\end{array}$} \\
\hline & & SLV & DLV & $\begin{array}{l}\text { SLV } \\
(\mathrm{mm} \\
\mathrm{Hg})\end{array}$ & $\begin{array}{l}\text { DLV } \\
(\mathrm{mmH} \\
\mathrm{g})\end{array}$ & & & \\
\hline 1. LNB & 10 & & 10 & & 8 & Minimal & $\begin{array}{l}30 \\
\min \end{array}$ & No \\
\hline 2. LND & 2 & 2 & & 6 & & $150 \mathrm{ml}$ & $4 \mathrm{hrs}$ & No \\
\hline 3. TYM & 8 & 2 & 6 & 6 & 8 & $150 \mathrm{ml}$ & $\begin{array}{l}3.5 \\
\mathrm{hrs}\end{array}$ & No \\
\hline 4. RSG & 2 & 2 & & 6 & & $150 \mathrm{ml}$ & $\begin{array}{l}4.5 \\
\text { hrs }\end{array}$ & No \\
\hline 5. TS & 8 & & 8 & & 8 & Minimal & $\begin{array}{l}30 \\
\mathrm{~min}\end{array}$ & No \\
\hline 6. SPL & 6 & & 6 & & 8 & Minimal & $1 \mathrm{hr}$ & No \\
\hline 7. LB & 14 & & 14 & & 8 & Minimal & $\begin{array}{l}20 \\
\mathrm{~min}\end{array}$ & No \\
\hline 8. OSE & 15 & 10 & 5 & & 8 & $\begin{array}{l}100- \\
150 \mathrm{ml}\end{array}$ & $2 \mathrm{hrs}$ & No \\
\hline
\end{tabular}

LNB - Lymph node biopsy LND - Lymph node dissection
TYM - Thymectomy, RSG - Retrosternal goiter TS - Thoracic sympathectomy

SPL - Bilateral splanchnicectomy

LB - Lung biopsy

OSE - Mobilization of thoracic oesophagus in three stage oesophagectomy

SLV - Single lung ventilation

DLV - Double lung ventilation

The average insufflation pressure used was noted to be $6-8 \mathrm{mmHg}$.

Table 2 Respiratory parameters

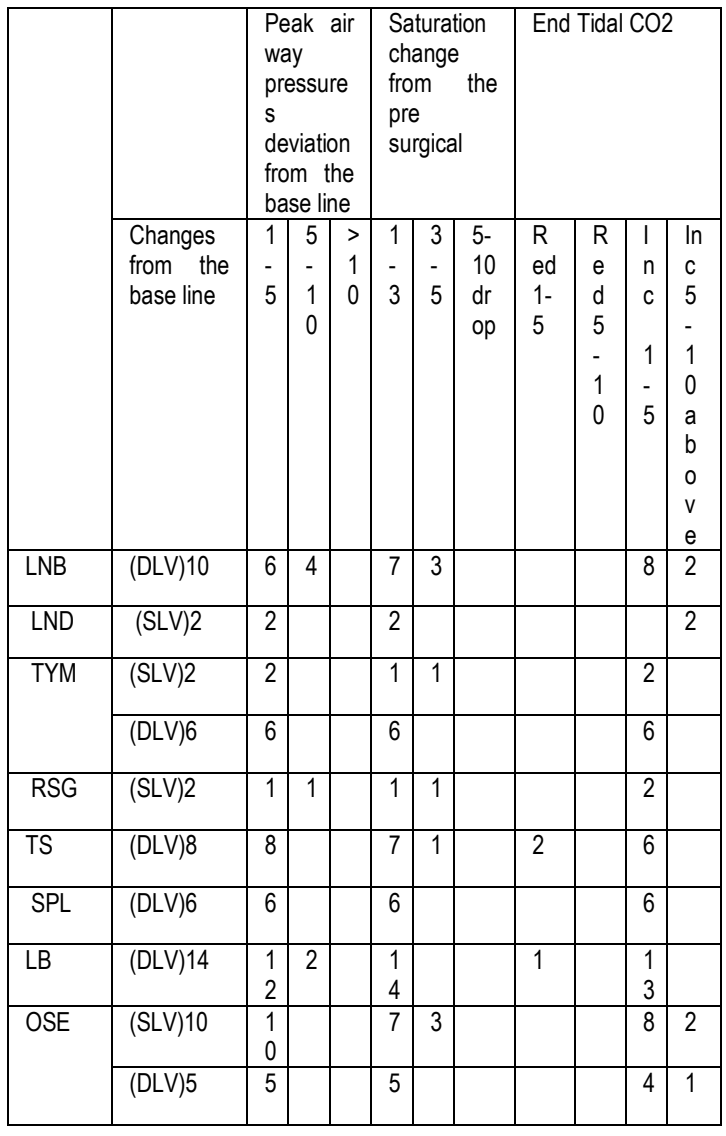

There was no reduction of oxygen saturation or significant rise of end tidal $\mathrm{CO}_{2}$. There was no significant deviation of the peak airway pressure from baseline. 
Table 3 Haemodynamic parameters

\begin{tabular}{|c|c|c|c|c|c|c|c|c|c|c|}
\hline & \multirow{2}{*}{$\begin{array}{l}\text { Procedure } \\
\text { Changes } \\
\text { from the } \\
\text { base line }\end{array}$} & \multirow[t]{2}{*}{$\begin{array}{l}\text { Hea } \\
\text { cha }\end{array}$} & & \multicolumn{3}{|c|}{$\begin{array}{l}\text { Blood } \\
\text { Pressure } \\
\text { change } \\
\text { (Sys) }\end{array}$} & \multicolumn{3}{|c|}{$\begin{array}{l}\text { Blood } \\
\text { Pressure } \\
\text { change (Dia) }\end{array}$} \\
\hline & & & $\begin{array}{l}2 \\
0 \\
- \\
3 \\
0\end{array}$ & $\begin{array}{l}3 \\
0 \\
- \\
4 \\
0\end{array}$ & $\begin{array}{l}1 \\
0 \\
- \\
2 \\
0\end{array}$ & $\begin{array}{l}2 \\
0 \\
- \\
3 \\
0\end{array}$ & $\begin{array}{l}3 \\
0- \\
4 \\
0 \\
a \\
b \\
0 \\
v \\
e\end{array}$ & $\begin{array}{l}1 \\
0 \\
- \\
2 \\
0\end{array}$ & $\begin{array}{l}2 \\
0 \\
- \\
2 \\
5\end{array}$ & $\begin{array}{l}25 \\
- \\
30 \\
\text { ab } \\
\text { ov } \\
\text { e }\end{array}$ \\
\hline LNB & (DLV)10 & 10 & & & & & & & & \\
\hline LND & $(\mathrm{OLV}) 2$ & 2 & & & & 1 & 1 & 2 & & \\
\hline \multirow[t]{2}{*}{ TYM } & (OLV)2 & 2 & & & & 1 & 1 & 2 & & \\
\hline & (DLV)6 & 5 & 1 & & & 6 & & 6 & & \\
\hline$\overline{R S G}$ & $(\mathrm{SLV}) 2$ & 1 & 1 & & 1 & 1 & & 2 & & \\
\hline TS & (DLV)8 & 8 & & & 8 & & & 7 & 1 & \\
\hline SPL & (DLV)6 & 6 & & & 6 & & & 6 & & \\
\hline LB & (DLV)14 & 11 & 2 & 1 & $\begin{array}{l}1 \\
4\end{array}$ & & & $\begin{array}{l}1 \\
4\end{array}$ & & \\
\hline \multirow[t]{2}{*}{ OSE } & $(\mathrm{SLV}) 10$ & 6 & 4 & & 3 & 4 & 1 & 9 & 1 & \\
\hline & (DLV)5 & 3 & 2 & & & 5 & & 5 & & \\
\hline
\end{tabular}

All systolic and diastolic blood pressure changes were within a range of $10-20 \%$ recording no major change. No significant changes of heart rate was noted.

\section{Discussion}

Lung can be collapsed during thoracoscopy by single lung ventilation. To promote the collapse initially $\mathrm{CO}_{2}$ has to be introduced in to the pleural cavity by insufflation. Continuous insufflation is not required if the bronchus is successfully blocked. While the lung is being ventilated, a partial lung collapse can also be obtained by the creation of a capnothorax. In this situation continuous $\mathrm{CO}_{2}$ insufflation was used not only to promote the initial collapse but to maintain the collapse. Looking at the results it is seen that in single lung ventilation the required insufflation pressure was $6 \mathrm{mmHg}$. With double lung ventilation insufflation pressure had to be maintained at $8 \mathrm{mmHg}$. In both situations the lung collapse obtained was adequate to visualize the anatomy and perform a safe dissection. The completeness of the dissection with minimal blood loss, in acceptable time, and having no conversions to thoracotomy can be considered as a surrogate for the adequacy of the space created.
In the range of $6-8 \mathrm{mmHg}$ insufflation pressure there were no adverse respiratory or cardiovascular complications inferring the safety of the pressure in the thorax.

\section{Conclusion}

With an insufflation pressure of $6-8 \mathrm{mmHg}$ an adequate lung collapse can be obtained for thoracoscopy. This pressure did not have any adverse respiratory or cardiovascular effects.

\section{References}

1. Findik G, Gezer S, Sirmali $M$ et al. Thoracotomies in children. Pediatr Surg Int. 2008;24(6):721-5.

http://dx.doi.org/10.1007/s00383-008-2144-6 PMid: 18414878

2. Cohen M, Yaniv Y, Weiss $\mathrm{J}$ et al. Median sternotomy wound complication: the effect of reconstruction on lung function. Ann Plast Surg. 1997;39(1);36-43.

http://dx.doi.org/10.1097/00000637199707000-00006

PMid:9229090

3. Grmoljez PF, Barner HH, Willman VL, Kaiser GC. Major complications of median sternotomy. Am J Surg. 1975;130(6);679-81. http://dx.doi.org/10.1016/00029610(75)90419-5

4. Yuen JC, Zhou AT, Serafin D, Georgiade GS. Long-term sequelae following median sternotomy wound infection and flap reconstruction. Ann Plast Surg. 1995;35(6);585-9.

http://dx.doi.org/10.1097/00000637$\underline{199512000-00005}$

PMid:8748339

5. McKenna RJ Jr, Benditt JO, DeCamp M et al. Safety and efficacy of median sternotomy versus video-assisted thoracic surgery for lung volume reduction surgery. Thorac Cardiovasc Surg. 2004;127(5);1350-60. http://dx.doi.org/10.1016/j.jtcvs.2003.11.025 PMid: 15115992

6. Zacharias A, Habib RH. Factors predisposing to median sternotomy complications. Deep vs superficial infection. Chest. 1996;110(5);1173-8.

http://dx.doi.org/10.1378/chest.110.5.1173 PMid:8915216

7. Mark TJ, Hooper TL. Video assisted thoracic surgery in introduction to Minimal Access Surgery. BMJ publishing group. 1995;62-64 PMid:7850299

8. Cusheri A, Steele RJC. Surgical craft and technology in Essential surgical practice 4th ed Arnold 1995;45

9. Dapri G, Himpens J, Cadière GB. Robotassisted thoracoscopic esophagectomy with 
the patient in the prone position. $J$

Laparoendosc Adv Surg Tech A.

2006;16(3);278-85.

http://dx.doi.org/10.1089/lap.2006.16.278

PMid:16796441

10. Rückert JC, Gellert K, Einhäupl K, Müller JM. Thoracoscopic thymectomy for treatment of myasthenia gravis. Zentralbl Chir. 1998;123(5):506-11.

PMid:22462219 